\title{
NOÇÕES DA ARTE DA ARMARIA (II).
}

\section{(Conclusão) .}

\section{IV. - Período elevado da armadura. Dos meados do século XIV até os meados do século XVI. Período culmlinante da armadura.}

Até 1630 , aproximadamente, as deças componentes da armadura foram lisas e acusavam apenas imperfeitamente as formas do corpo humano. Dali a poucos anos já apresentavam contornos elegantes: as sôlhas são tôdas anguladas nos centros em aresta e rebatidas em planos encontrados, a fim de quebrar a monotonia das superfícies, como depois se praticou de modo mais sensível nos peitos das couraças.

As cotoveleiras e as joelheiras (Fig. 22), mais completas, foram encaixe ao cotovelo e à rótula, tendo ambos já guarda exteriores, isto é, lâminas arredondadas, ovais, e às vêzes em meia-lua ou em crescente, facetadas e recortadas em estilo ogival e com elegância. Começam a falda e as escarcelas a serem, em vez de lisas, contornadas em linhas ondulantes e rebatidas em estrias largas, côncavas ou convexas, de estilo ogival, variadas̀ sempre, assim como também as guardas. E' - período dos arnezes góticos. As articulações das sôlhas (braçais e caneleiras) multiplicam-se; a caneleira, descendo mais baixo, contornando e deefndendo o tornozelo.

O capacete sofre, próximo ao fim do século, modificações: aparece e em breve se generaliza, um novo invento, o chapéu de armas ou chapéu de ferro, que defendia a cabeça, junto com o camal e completava o arnez de combate do Infante $D$. Henrique, na célebre jornada de Ceuta, em que tanto se distinguiu, pois assim o revelou Azurara em sua Crônica. Esta nova arma deefnsiva não era mais do que a imitação dos sombreiros ou chapéus do século XV. Tiveram variadíssimas formas: copa baixa com tendência piramidal muito achatada e com uma aba derrubada em faixa larga em tôda a circunferência, cône truncado elevadíssimo e de aba com rebordo; outros houve de forma de zimbório ogival e de aba larga horizontal, etc. Alguns anos depois de inventados, aparecem-nos com dois chanfros laterais, no lugar das orelhas e estas defendidas por duas chapas em concha, de cunho gótico, muito pronunciado, fixas na aba. Usavam-se com o camal. 


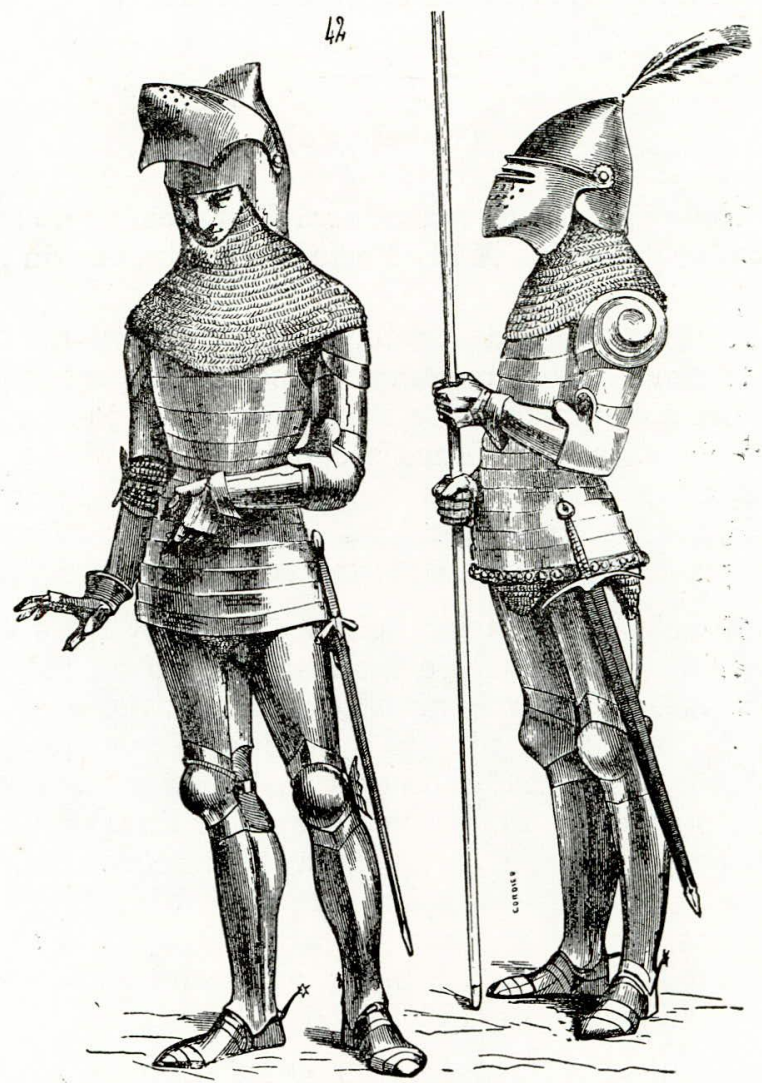

Fig. 22. - Armadura do século XV, notando-se o bacenete de malhas, cotoveleiras e joelheiras (E. Viollet-le-Duc, pág. 128).

Alguns chapéus de ferro tiveram um vergalhão de ferro também, isolado da copa e pendente em sentido vertical para diante do rosto para a defesa desta.

O chapéu de armas esteve em voga durante quase todo o século XV, reaparecendo depois de tempos em tempos, porém, apenas como fato isolado, filho da fantasia pessoal, tornando a usar-se nos meados do século XVII.

Nos fins do século $\mathrm{XV}$ vem da Itália com as hordas de mercenários, a moda da celada (do italiano celata), cujo tipo (Fig. 23) mais comum era o de um boné de pala, posta esta para a nuca e enterrada pela cabeça abaixo até as sombrancelhas; à altura dos olhos tinha uma abertura horizontal, por vêzes di- 

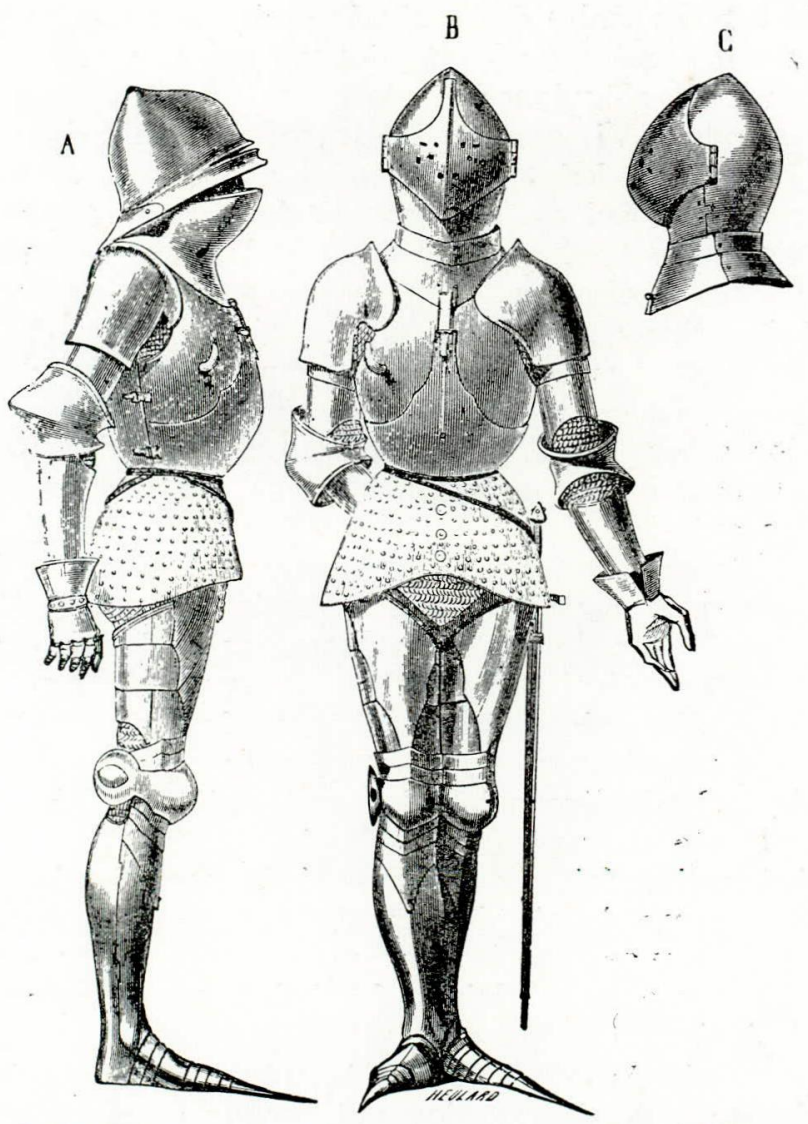

Fig. 23. - Armaduras do século XV. Observar A - elmo "celado", sem viseira; B - bacenete com gorjal; C - bacenete simples com aberturas laterais. (Violletle-Duc, op. cit., pág. 139).

vidida em duas; em algumas depois se acrescentou a viseira. Generalizou-se muito, logo desde seu aparecimento, a celada; e desde o fim do século XV até ao segundo quartel do XVI, substituiu quase por completo o chapéu de ferro que se usava principalmente nos arnezes para se combater a pé.

$O$ aperfeiçoamento do arnez deu motivo a que os cavaleiros, já nos fins do século XIV, fôssem pondo de parte as malhas. No século XV já apenas se usavam guarnições destas nos falsos ou soluções de continuidade que apresentavam as sôlhas nas juntas; invergavam estas últimas sôbre um fato completo de pele de gamo, estofado ou acolchoado nos luga- 
res onde o ferro tinha de se cingir mais ao corpo para amparar a ação dos golpes; alguns contudo conservavam o saio de malha, que foi abandonado, quase em absoluto, nos primórdios do século XVI, quando foi introduzida a brigantina (de origem italiana $=$ brigadina), a qual não parece corresponder an jubanete que Rui de Pina nos diz ter sido encomendado do estrangeiro para Portugal por D. João II, para armamento da sua cavalaria ligeira ou gineta e das guardas de corpo.

A brigantina constava de uma espécie de corpete de abas ou faldra curta ou jaque, composto na sua totalidade por escamas pequenas sobrepostas e de contôrno gótico trilobado, assentados sôbre um fôrro de estôfo acolchoado, através do qual passavam os botões semi-esféricos dos parafusos que fixavam as escamas.

Supôs-se por muito que as escamas fôssem usadas para fora, mas era ao contrário, circunstância que resulta bem clara das iluminuras da época; as escamas andavam para dentro; e a parte visível era o estôfo que por vêzes se apresentava rico e adornado, e tem os botões de metal valioso. Parece que o uso de uma cota semelhante a esta se prolongou até o século XVI; é mencionada por Damião de Góes num dos seus escritos e chamava-lhe de laudel.

A brigantina foi por longo período peça fundamental do arnez, e, mesmo depois de ter vindo a couraça completar a armadura, ficou-se usando com as calças e braços de malha $r \in$ forçados com as cotoveleira e joelheira, nos armamentos chamados à ligeira.

Com a adoção geral da celada coincide a entrada de um novo elemento de defesa, do qual resultou uma alteração de máxima importância no arnez, e que contribuiu para lhe fixar a forma definitiva: é o barbote, cujo nome indica a forma e o destino que teve.

O barbote era uma peça que defendia o queixo e a barba, contornando esta, prolongando-se daí pelo pescoço em lâmina larga para o defender, e assentando afinal no peito; ao barbote foi necessário, em breve o gorjal ou gorgelim, espécie de colar que rodeava o pescoço e se espraiava em cobeção curto, assentado sôbre o peito, costas e parte dos ombros.

Assumiu bem depressa o gorjal importância máxima; ficou sendo a chave do arnez; dêle se suspendia o pêso principal das peças; afivelavam-lhe as bafurneiras ou braçais de espaldeiras muito deesnvolvidas, o que causou a supressão das rodelas do peito e do corselete ou meia-couraça. 
Em 1460 aparecem muitas armaduras com o peitoril e espaldar completos e subindo até a altura do Gorjal: é a couraça ainda não inteiriça, mas sim fabricada de lâminas articuladas e scbrepostas, deixando ao centro uma superfície mais larga para a defesa do torax.

As primeiras couraças são ainda arredondadas, muito bojudas e com a cintura muito acentuada; pouco depois, vamos encontrar facetadas, com a aresta central verticalmente acusada. A couraça do fim do século XV é muito elegante.

De 1480 em diante, passa a couraça a ter o peito e as costas inteiriças; e é logo aproveitada a superfície larga que oferece o peito de aço para a aplicação de um melhoramento importante, o fulcro, reste ou riste (corruptela do vocábulo inglês rest). Era uma haste ou gancho de ferro com quatro faces curvas e de forma variável, fixa a um espigão pregado na couraça do lado direito e dobrando em ângulo na direção do braço direito. Servia ao cavaleiro para apôio da lança sobraçada quando acometia o seu contrário; daí a expressão enristar a lança ou pô-la em riste (Fig. 24).

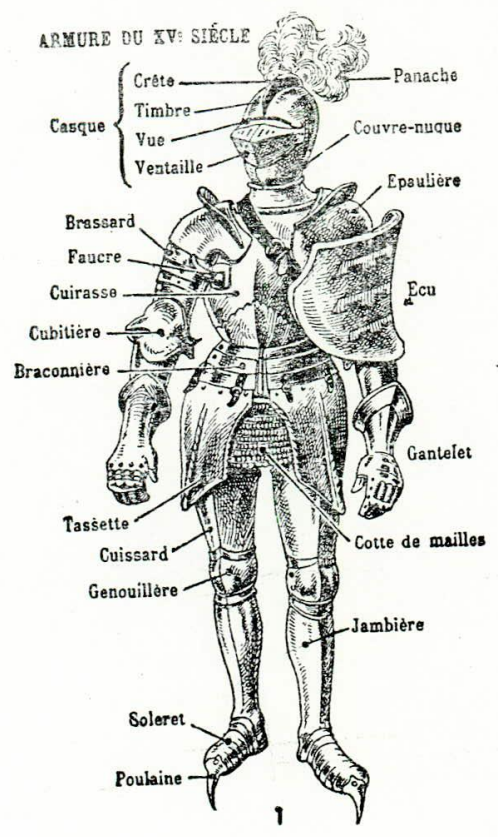

Fig. 24. - Armadura do século XV. (Larousse, op. cit., pág. 351). 
A couraça foi a conseqüência lógica de um novo invento, o qual, mais tarde atingindo, perfeição relativa, estava destinado a operar uma revolução completa na armaria: as armas de fogo.

O arnez já caminha a passos largos para o seu último aperfeiçoamento como defesa do corpo humano.

Ao gorgegelim e barbote tinham sido acrescentadas várias lâminas articuladas para encerrar e abrigar completamente o pescoço; a nuca era defendida pela enorme aba ou guardanuca da celada. Em vez destas peças separadas, aparece uma nova forma de capacete em que as peças constituiam um todo: é o elmete ou elmo de viseira que participa do caráter da celada e do elmo antigo, e que ficou sendo o tipo definitivo do capacete do cavaleiro, o qual, salvo modificações artísticas de feitio, só deixou de se usar absolutamente no século XVII.

Vejamos agora minuciosamente como estava constituída a armadura completa no último quartel do século $\mathrm{XV}$ e princípic do século XVI.

Compunha-se das seguintes partes: (Fig. 24).

$1 .^{\circ}$ - Celarda de barbote e depois elmo cerrado de viseira;

$2 .^{\circ}$ - Gorjal com os anexos articulados;

$3 .^{\circ}$ - Peito da couraça;

$4 .^{\circ}$ - Espaldar da couraça;

$5 .^{\circ}$ - Espaldeiras;

$6 .^{\circ}$ - Braçais e avan-braços (bafurneira);

7..$^{\circ}$ - Cotoveleiras e guardas;

$8 .^{\circ}$ - Faldra;

$90^{\circ}$ - Escarcelas;

$100^{\circ}$ - Coxotes;

$110^{\circ}$ - Joelheiras com guardas exteriores;

$12 .^{\circ}$ - Caneleiras duplas ou grevas;

$13 .^{\circ}$ - Guantes;

$14 .^{\circ}$ - Sapatos de ferro.

A greva e o coxote duplo são os últimos aperfeiçoamentos do arnez no século XVI.

As sôlhas duplas das pernas constituem pois a indicação cronológica mais importantes para classificar com exatidão a época de um arnez completo.

A armadura conserva ainda grande parte do seu caráter gótcio até ao fim do primeiro quartel do século XVI. Adaptase sempre à forma humana e é elegantíssima e cheia de bom gôsto nos pormenores. O trabalho artístico mantém-se sempre 
no limite das fórmulas apropriadas ao metal empregado, o ferro ou o aço; e tôda a atenção dos armeiros dos períodos ogivais parece ter-se concentrado no aspecto e no caráter geral da armadura.

Os artistas do Renascimento neo-clássico foram inferiores aos seus antecessores em tudo quanto inventaram: nas formas acusaram decadência; desviaram a elaboração artística do arnez do seu verdadeiro fim; sobrecarregaram-no de ornamentos, já gravados, já rebatidos e relevados, e por êsse motivo o trabalho da generalidade dos arnezes do século XVI, tanto pode pertencer a ourivesaria ou a escultura de madeira como a qualquer outro ramo suntuário, tem entretanto quase sempre grande valor como espécime de ornamentação. Deixaram obras primas neste gênero: Wohlgemuth, Alberto Dürer, Benevenuto Cêllini, Arfé de Villafana e muitos outros.

Uma circunstância, aliás importante, tiveram a seu favor os artistas do último período ogival; foi a imperfeição das armas de fogo, que permitia fazer as sôlhas delgadas e portanto mais fáceis de adaptar a forma do corpo humano. A medida que a arma explosiva se ia aperfeiçoando, o arnez aumentou em espessura até se tornar insuportável, a ponto de ninguém poder com êle. A armadura do século XVII com a sua pesadíssima couraça tornou-se uma fábrica de congestões e de apoplexias; e as feridas produzidas pelas balas nas pernas, agravadas pelos estilhados das grevas, tinham quse sempre como conseqüência obrigada a mutilação; eis a razão porque se abandonaram em tôda parte quase ao mesmo tempo, isto é, no último quartel do século XVI.

A armadura de torneio era, já em 1450 , muito mais pesada do que o arnez de pelêja. O elmo enorme e pesadíssimo de viseira fixa, aparafusado ao espaldal; o manto de armas, escudo fixo que se sobrepunha ao peito de aço e contornava o ombro esquerdo e braço, e que em muitos casos tinha uma babeira ou barbote anexo; uma falsa caneleira grossíssima que se sobrepunha à greva para defender a perna das contusões nos barrotes da teia que fechava a arena ou corredor, pelo qual os cavaleiros despediam ao galope dos corcéis até se encontrarem frente a frente com o adversário. Tudo isso assume, no início do século XVI proporções extravagantes. Conservam-se também nas justas as sobrecotas farpadas e chapadas com timbres heráldicos e impressas, e encimando o elmo ornamentos de couro pintado e forrado ou plumas de proporções exageradas. 
As selas, arreios, esporas, estribos, etc., chamam a nossa atenção pela sua singularidade.

Antes do século XIV não oferecem as selas, quer de batalha, quer de torneios, grande interêsse artístico, a não ser o da fisionomia própria a cada época em especial.

De 1480 em diante começa a aparecer a sela de guerra, a brabante, a qual, embora fôsse depois sujeita a inúmeras e caprichosas variantes, parte sempre de um princípio fixo, a saber: o de acrescentar algo à estatura do cavaleiro e permitir-lhe o manêjo das armas, desafrontado da cabeça do cavalo. Para chegar a êste resultado havia o assento ou coxim da sela de Brabante, cuja armação era de madeira coberta de sola e depois também barbada de ferro, suspenso por quatro ou seis grossos varões de ferro. $\mathrm{O}$ assento era extremamente exíguo: a forquilha e a patilha formavam como dois parapeitos barbados também, entre os quais ia instalado o cavaleiro. Êste, além da posição incômoda, era obrigado a levar as pernas hirtas e verticais, firmando os pés em estribos que, dia após dia, foram sendo cada vez maiores e mais pesados para de alguma forma ajudarem o equilíbrio.

Houve outra forma de sela, a chamada sela da gineta, que pouca diferença faz das selas dos séculos imediatos.

A espora, sim, variou muito: as de torneio eram esporões enormes, com três e mais rosetas e que mais parecem instrumentos de tortura; eram uma necessidade filha da posição forçada do cavaleiro, que de outra forma não poderia tocar sequer a barriga do cavalo. O livro de D. Duarte, Livro da Ensenança de bem cavalgar, que é uma tradução do Tornois du roi René, nos dá uma idéia de quanto era difícil e constituia mesmo uma arte, o cavalgar com acerto e elegância.

No último período da armadura gótica, ou na transição para o Renascimento, acrescenta-se à espaldeira, por si já bastante grande, uma nova peça: é a guarda de ombros, ou o guarda colo, lâmina grossa, circular e impinada sôbre o ombro, que defende os golpes ao pescoço. Daí a pouco a faldra e as escarcelas reunidas numa só peça, formam uma saia de ferro, o saio, que depois muito exagerado em comprimento se fica chamando tonelete (Fig. 14); era a imitação do "saio de pregas" ou "saio a tedesca" que as gravuras de Alberto Dürer tornaram tão conhecido, semelhante peça caracteriza as armaduras que se destinavam a combater a pé. 
Há ainda no período de transição a registrar um arnez que, embora já mais pesado na essência e no aspecto, é ainda belo pelo caráter grandioso que apresenta e pela ornamentação original: é a armadura maximiliana, designação imprópria que implica um justo olvido do nome do seu verdadeiro autor, o célebre mestre Albrecht, armeiro do imperador Maximiliano e tálvez o primeiro entre os seus êmulos. Esta espécie de arnez apresenta como características distintivas elegantes estrias ou caneleiras que lhe adornam as espaldeiras-cotoveleiras, a região do peito de aço, e às vêzes as escarcelas e os pés de ferro, ou o tonelete em alguns casos. E' perfeita como defesa, pois quase nenhuma solução de continuidade oferece a junção das peças que a compõem. Como arma de coleção, é das mais apreciadas. E' possivel que tenha sido usada em Portugal, nessas festas suntuosas dadas em Évora por El-Rei D. João II, por ocasião do casamento de seu malogrado e único filho, D. Afonso que se casou com Isabel, filha dos Reis Católicos e das quais Rui de Pina e Garcia de Rezende nos deixaram tão pitorescas narrações, pois por essa ocasião mandou El-Rei vir do estrangeiro grande quantidade de alfaias e apercebimentos.

Talvez figurasse mais tarde no armazém das armas de D. Manuel entre êsses cavaleiros montados em cavalos de pau, tanto ao vivo e pelo natural, etc., que excitaram a ingênua admiração do bom padre Sande (9), o qual descreve a armadura maximiliana (sem elmo) pesando cêrca de 24 quilos; e as de torneio muito mais. Entretanto, cabe aqui uma observação que vai de encôntro à idéia de serem os homens da Idade Média mais avultados em musculatura e estatura que os de hoje. Deve admitir-se exatamente ao contrário como verdade reconhecida, porque ao percorrer as coleções de armas, salta logo a vista o fato de serem na sua grande maioria as armaduras pequenas e exíguas, principalmente as grevas, que ficam tôdas apertadas a qualquer perna regular dos nossos dias. Só encontramos uma exceção: Henrique VIII, rei da Inglaterra, que media 2 metros e 8 centímetros e pesava mais de 100 quilos. Seus armeiros de Greenwich, deram tratos à mente em 1540 para fabricarem uma armadura de proporções tão grandes.

A maximiliana é a fórmula do arnez que representa verdadeiramente o gótico florido no seu último período.

(9). - Narrativa encontrada na "Viagem da Embaixada do Japão a Europa no século XVI", publicada posteriormente no Arquivo Pitoresco. 
A armadura para os homens de 1500 foi mania dominante; e os cinqüenta ou sessenta anos seguintes tornou-se uma questão de amor próprio e uma causa freqüente de ruína. Começaram as armas de luxo. E já nessa época se encontram notícias de vários gabinetes de armas, onde abundavam inúmeras peças ùnicamente decorativas; daí encontrarmos tanta arma cujo feitio denota a impossibilidade de ter alguém jamais feito uso dela.

A armadura do cavalo, conseqüência lógica do arnez do cavaleiro, completa-se ao mesmo tempo que aquela. Chegou a vez dos pobres cavalos, que, como contrapeso ao muito com que já carregavam, passam a ser todos também cobertos de ferro ou de aço.

A armadura do cavalo abrangia no seu conjunto as seguintes partes: a testeira, rostrada ou não rostrada, com duas guardas para as orelhas, sobreposta a um capuz de malhas que cobria também o pescoço, guarnecida em todo o comprimento dêste com lâminas articuladas (a barba ou pescoceira); o barbão ou tonelete de ferro que cobria a anca tôda e com um prolongamento em lâminas qưe defendia parte da cauda; os ilhais, peças soltas a laia de escarcelas, que completavam um pesado peitoral de ferro.

Por vêzes acrescentou-se à testeira uma focinheira em gradeamento de ferro; existem raros exemplares desta peça artisticamente trabalhados, que parecem contudo ter sido reservedos para torneios.

Usou-se também, e com mais freqüência então, armar o corcel à ligeira, cobrindo-o com uma espécie de loregão de malha, ao qual se sobrepunham atafais ou arreios bordados de cadeia de ferro ou aço.

$\mathrm{Na}$ Alemanha chegaram a fabricar coxotes e caneleiras, e mesmo grevas para cavalos, o que é bem de supor não passasse dt casos excepcionais e objetos de mera ostentação e vaidade artística.

Acompanhemos o arnez até vê-lo atingir o seu máximo grau de adiantamento e evolução.

Lancemos agora uma vista de olhos para as armas ofensivas e vejamos como acompanharam a evolução das outras.

Poucas inovações há a registrar nesta secção desde o século anterior, além do que já mencionamos com respeito ao conjunto das armas brancas e de haste, conjunto que foi comum a todo período gótico até ao alvorecer do Renascimento, cedendo então pouco a pouco o. lugar às novas armas explo- 
sivas, logo que estas se foram aperfeiçoando em alcance, brevidade e precisão de tiro.

Nos fins do século XV já tinham desaparecido algumas armas de haste, tais como a vouldge (foice ou venábulo de assédio), a áscuma (espécie de venábulo de caça arvorado em arma de gúerra, correspondendo ao goedengag flamengo, dardo pesadíssimo muito grosso e curto da haste que era esquinada), a bisarma terrível e o desmontador ou derrubador.

Começa com o século XVI a generalizar-se a elegante partasana (alabarda aguda e larga da infantaria) favorita dos guardas de palácios e alcáceres régios, partilhando essa honra com a rendilhada alabarda do mesmo período.

A besta, material e artisticamente aperfeiçoada, é quase sempre de aço desde o fim do século XV; cai em desuso, como arma de guerra, durante a primeira metade do século XVI e fica reduzida a arma de caça até quase ao XVIII século.

As armas de fogo parecem que se generalizaram muito depressa em Portugal, e a dissoluc̃̃o dos corpos de besteiros por El-Rei D. Manuel precede tôdas as medidas do mesmo gênero na Europa (10).

O pique, o chuço e a alabarda, ficam sendo, por longo tempo ainda, armas de infantaria.

A espada e o punhal não oferecem por ora o interêsse e a variedade artística que deviam assumir durante o Renascimento e períodos seguintes.

A espada do século $\mathrm{XV}$ tem quase sempre o punho em cruz; o punho é mais longo que o das espadas das outras épocas, e já é bastante rico e adornado por vêzes, conservando o estilo ogival.

Adota-se a espada para ambas as mãos, cujo uso se torna extensivo à infantaria, parecendo ter sido introdução dos alemães, em cujas mãos era uma arma terrível.

A adaga, forma intermediária entre a espada e o punhal, foi ainda uma arma do século XV. Era a espada do peão e foi sujeita a inúmeras variantes, das quais a mais singular é a adaga língua de vaca, gládio larguíssimo, cuja forma o nome indica; descendem desta a mão esquerda (punhal traiçoeiro dos duelos à espada e das emprêsas noturnas dos fins do Renascimento), o quebra espadas (Fig. 25), adaga larga e o chifarote (arma de origem italiana).

(10). - Este monarca, segundo seus biógrafos, foi muito propenso à artilharia e assistiu mais de uma vez a experiências de "bôcas de fogo", algumas das quais eram invento de sua própria autoria. 

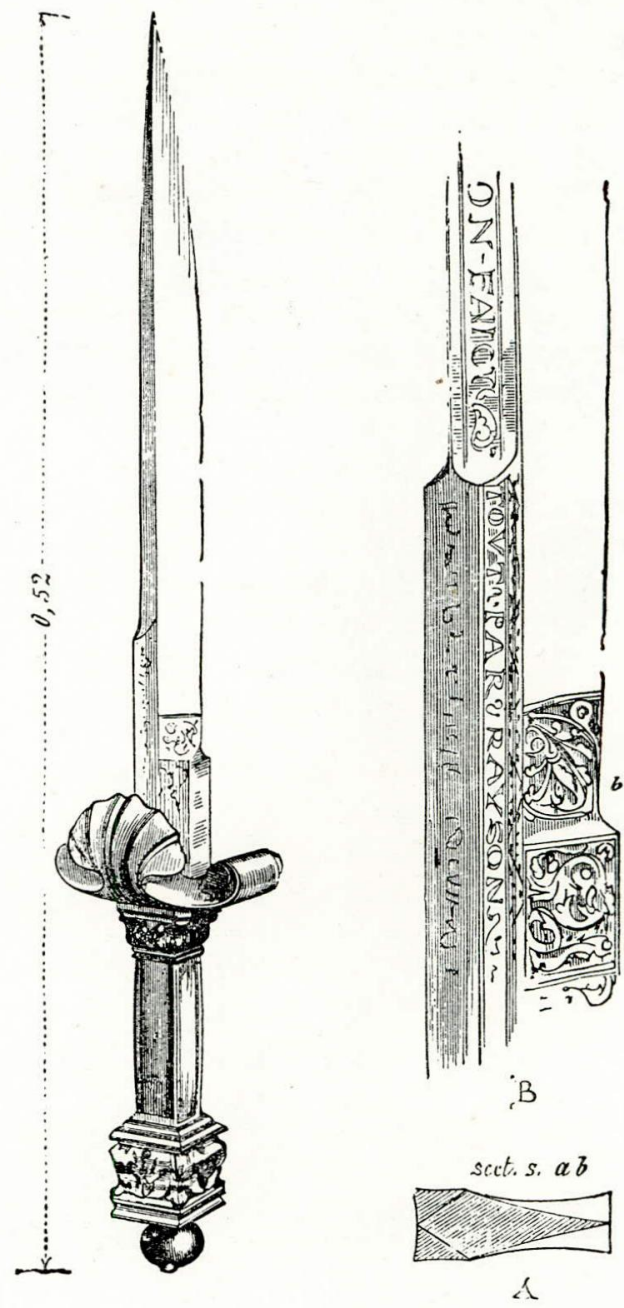

Fig. 25. - Adaga quebra-lâminas ou quebra-espadas. Século XV. (Viollet-le-Duc, op. cit., pág. 320 ) .

A espada flamejante tinha uma fôlha em zigue-zague e era de dois gumes como quase todos os gládios dos séculos XV e XVI, com exceção do chifarote, que era triangular, semelhante a baioneta do século XVIII. Parece ter sido invenção suiça. Usou-se muito depois na defesa contra investidas de muralhas, assim como também a espada de ambas as mãos. 
O escudo e o broquel (do alemão antigo bückel), a targa, ou tarja, a adarga, o pavez e a rodela, são os escudos dos séculos XIV, XV e XVI.

A tarja era o escudo das lições, justas e torneios; tinha forma retangular curva, regular ou irregular; era, como quase tôdas as variantes do escudo, de madeira ou de sola bordada de metal.

O escudo pròpriamente dito tinha as diferentes formas que a heráldica depois consagrou. (Fig. 26).

O broquel é o escudo das éras remotas.

A adarga é um escudo redondo pròpriamente peninsular, imitado dos muçulmanos hispânicos. (Fig. 27) .

A rodela também redonda é menor, muito convexa e tôda coberta de lâminas de metal. Era o escudo de mão; não se embraçava como os outros. Nos séculos XVI e XVII os oficiais eram obrigados a trazer a espada e rodela, pendurada à cinta.

A peonagem, apesar de reagir por instinto contra a armadura de ferro (quer completa, quer de malhas e peças ou sôlhas), já ia nos fins do século XIV, e a fôrça de lho imporem com penalidades severas, obedecendo pouco a pouco e habituando-se a revestir-se com o espólio de guerra dos cavaleiros, as mais das vêzes.

Nos séculos XV e XVI vai aumentando a regularidade do armamento, e em certos corpos escolhidos a armadura encontra-se já quase tão completa como a do cavaleiro vilão (pelo menos) à exceção do elmo fechado que ficou sendo sempre privativo do cavaleiro e do nobre, como menciona Santa Rosa de Viterbo, em seu Elucidário, ordenações régias decretando e impondo formas de armamento aos alardos ou levas de tropas dos Conselhos.

Muitas das variadíssimas armas dos países setentrionais da Europa nunca foram usadas na Península Ibérica e principalmente em Portugal; além da freqüência das ordenações imperiosas impondo armamento aos peões, algumas passagens dos nossos clássicos ajudam a corroborar esta opinião.

$\mathrm{Na}$ descrição que Fernão Lopes faz na sua Crônica, da batalha de Aljubarrota, insiste no armamento deficiente dos cavaleiros portuguêses comparado com o dos espanhóis.

Azurara, na sua Crônica, em que descreve a tomada de Ceuta, refere-se mais de uma vez a indivíduos, a quem livrou da morte a carapuça de muitas voltas que levavam na cabeça. 
Era a comprida carapuça do século XV, que na Península se enrrolava em roda da cabeça como turbante mourisco, e que na Espanha se vê representada em esculturas tumulares até ao meado do século XVI.

Compreende-se que a grossura do estofo em camadas repetidas servisse de defesa à cabeça, acrescendo, de mais a mais, poupar o bacinete, insuportável aliás debaixo do ardente sol africano.

Depois do período das armas de luxo, veio a época da decadência .

$$
\text { \& }
$$

V. - Aspectos da armadura no último quartel do século XVIII (Períoldo de decadência e extinção da armadura e das armas de haste pela influência das armas de fogo).

Ao terminar o primeiro quartel do século XVI a armadura tende a declinar sensivelmente.

A couraça, imitando o pelote à flamenga, da época, encurta extraordinàriamente, imprimindo ao conjunto do arnez aspecto desproporcionado; achata-se o elmo de viseira e o barbote; exagera-se a guarda de ombros ou guarda-colo, suprimindo-se em seguida a do lado esquerdo (lado do escudo), provàvelmente para aliviar um pouco a carga do cavaleiro, o qual aparece nas pinturas e gravuras dêsses tempos com a forma aproximada de uma rã ou sapo colossal.

A ornamentação vai gradualmente invadindo a superfície do arnez; a princípio é a gravura à ponta sêca e à água-forte; depois segue-se o trabalho de embutidos de materiais valiosos (tuachiados, do alemão tauchierarbeit); e afinal os lavores em relêvo e rebatidos recobrem tôdas as peças defensivas; o armeiro eclipsa-se perante o gravador e o escultor.

Começa o delírio das armas de luxo e de mera ostentação: os grandes potentados, os testas coroadas, próceres e magnatas, trocam entre si presentes de armas; dá-se um elmo, uma adarga ou uma espada, como no século XVIII passa a oferecer-se uma caixa de rapé e posteriormente a pena de ouro ou a charuteira de preço. Esgota-se a invenção dos artistas: aa princípio os alemães e flamengos trazem a ornamentação imaginosa e rica de invenção do Renascimento germânico; seguem os italianos, ressuscitando as formas e tipos da Antigüidade pagã e criando os capacetes à la antiga, isto é, de imitação grega e romana, decorados com assuntos alegóricos e mitológicos, com figuras clássicas esculpidas nas cimeiras. 
Episódios guerreiros, em relêvo, cobrem escudos, adargas, peitos de couraça, e até os punhos das espadas e punhais ou adargas, tornando-se em breve escasso campo para seus devaneios a superfície tôda do arnez.

Contribuem nessas éras os mais reputados talentos da Europa para a decoração da armadura: esta, contudo, vai perdendo o caráter e a linha artística; arredonda-se-lhe a faldra completa ou tonelete, amesquinham-se-lhe as peças das juntas (cotoveleiras, joelheiras, etc.); cai-se pouco a pouco, fato aliás comum a tôdas as decadências artísticas, no grotesco, havendo também a notar as armas humorísticas: capacetes, cujas viseiras são carrancas, cabeças de animais e às vêzes armas falantes. Por outras vêzes o nome e o atributo do dono em charada figurada. Uma digna de menção dêste gênero é a extravagante armadura dos leões, que pertenceu a Luís XII de França.

Aí por 1560 , volta a mania do arnez grotesco, quando vemos imitados na armadura a forma, o corte e até o estôfo dos trajes à italiana, cujo gôsto invadiu nessa éra as côrtes principais da Europa. Figuram-se no arnez os calções, as mangas à wallona, as calças golpeadas, os borzeguins, e até a gorgueira de fôlhos.

Por vêzes o elmo representa a efígie do seu possuidor coberta com o gôrro ou barrete de plumas.

Testemunham êste fato a célebre armadura de Carlos $\mathrm{V}$. e outras.

Há em abundância nas coleções célebres um tipo de arnez completo e às vêzes de couraça como peça única de defesa, a que os franceses dão o nome de casca de ervilha (cósse de pois) ou "corcunda de Polichinelo", que efetivamente afeta a forma do gibão em papo de rôla daquele grotesco e legendário personagem da velha comédia italiana, o qual aparecia nos teatros forenses de Nápoles.

Este tipo de armadura, inspirado na França e noutras côrtes pelos comediantes italianos, e que se distingue por ter a couraça muito curta nos quadriz, estreita na cintura e proIcngada no estômago em bico e papo intumescente até a altura do umbigo, não tinha faldra nem escarcelas; começavam lcgo da cintura os coxotes que só paravam na joelheira e que passaram a ser articulados em lâminas muito repetidas e estreitas.

As armaduras dêste caráter, que os alemães chamaram kräbse ou lagosta, apresentam efetivamente uma certa seme- 
lhança com êsse crustáceo, e devem considerar-se pertencentes a um período mediando entre 1570 e 1600; as mais exageradas são as francesas.

E' raro terem grevas os arnezes dêste gênero, começando desde então a ser substituídas por grandes botas de pele de búfalo.

Apesar dêste sintomas visíveis de decadência, existe uma forma de arnez que muito se usou nestes tempos, e cuja forma é quase sempre elegante e sóbria, salvo por vêzes o exagêro e a impropriedade da ornamentação: é o cosselete, corselete, ou meia-armadura, couraça, completa de peito e costas, de faldra e escarcela ligadas numa peça única e às vêzes braçais completo (o meio-corpo de armas).

Algumas couraças existem também em cuja aba inferior, recortada e ornamentada, não se vêm buracos para correias nem vestígios de fivelas; usavam-se como peça única defensiva e eram um distintivo de oficial, como o ficou sendo o gorjal .

A armadura do século XVII tem a couraça de uma espessura desconforme para resistir às balas; é muito curta do busto e sem cintura; tem espaldeiras enormes e muito arredondadas, que àvançam sôbre o peito para melhor fecharem o arnez; o elmo muito redondo e de viseira achatada é inteiramente destituído de elegância; as articulações das lâminas multiplicamse nos braçais e coxotes inteiriços, o que nunca mais deixa de sc usar e recobrem-se de botões de metal amarelo; de grevas... nem vestígios, era em seu lugar a grossa bota, talhada numa perna de boi; os guantes têm, como na forma primitiva, os dedos divididos e miudamente articulados, para facilitar o manêjo da pistola.

Nos meados do século XVII cai em desuso o elmo, e é adotada geralmente a borbonhesca ou borguinhona, celada à moda de Borgonha, cuja forma é a da antiga celada com uma pala adicional para a testa. (Fig. 28).

O timbre ou copa (Fig. 29) é oval, encimado por uma crista que o acompanha em todo o diâmetro; tem dos lados duas peças, como as jugulares romanas, que defendem as orelhas e as faces; algumas vêzes, há um varão de ferro suspenso verticalmente num aro circular do mesmo metal e que se levanta ou abaixa para defesa da cara; outras vêzes, nota-se um estreito barbote e uma grade fixa de varões verticais para defesa do rosto.

O arnez completo dêste teor é absolutamente grotesco e dá ao cavaleiro o ar de um corcunda; é o seu último arranco. 


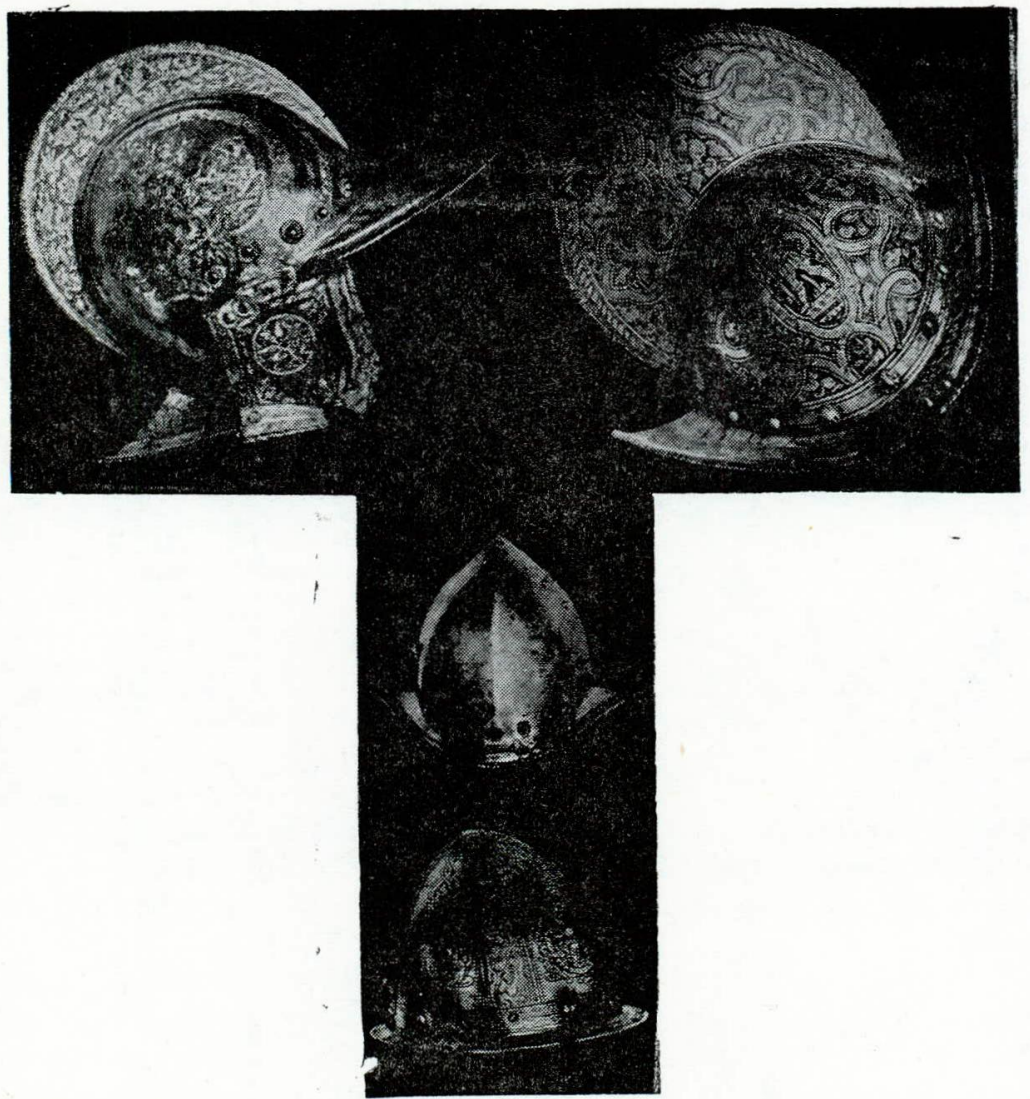

Fig. 28. - Capacetes do século XVI. (Weygand, op. cit., pág. 125). 1 - Baurguiguotte, dourada em ferro gravado. 2 - Morrião de infataria, em ferro gravado. 3 - Morrião cabacete . 4 - Cabacete simples de infantaria.

Constituira o tipo de armamento da cavalaria portuguêsa durante a guerra de defesa do Reino, posterior à Restauração de 1640, e fôra introduzido pelo Marechal de Schomberg (Armando Frederico, Duque de, 1615-1690).

No fim do século XVII a couraça deixa de ter marcada a aresta média do peito; redonda, longa e de um pêso insuportável.

A infantaria, desde a metade do século XVII, usa o meiocorpo de armas, apenas com meios-braçais, suprimindo depois o do braço direito; no fim do século, vestia apenas a couraça; esta, porém, é abandonada pela cavalaria que lhe substitui o gi- 


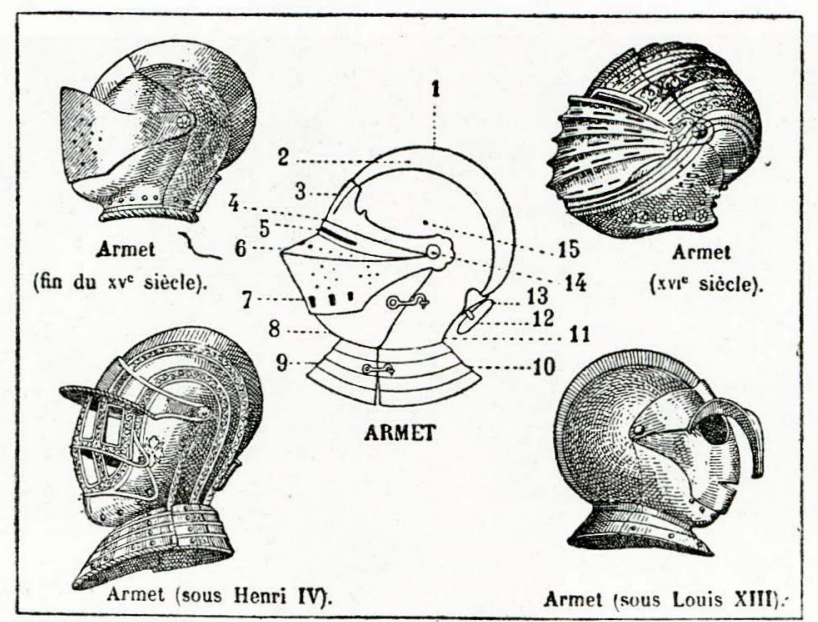

Fig. 29. - Vários tipos de elmos. (Larousse XIXe siècle, pág. 348). 1, crista; 2, orifício para fixar o penacho; 3, frontal; 4 e 6, nasal; 5 , viseiraé 7 , babeira; 8, fôlho da máscara; 9 e 10, gargantilha; 11, cabo do timbre; 12, virola do postigo; 13, porta-penacho; 14 , rebite e 15 , timbre.

bão de atanado (11), o qual se aperta com um largo cinturão de enorme fivela, pondo-se a tiracolo um bolbrié idêntico, e conservando-se o gorjal que passa a ser mais comprido; quase todos os gorjais, que se vêm nas coleções, são riquíssimos em decorações.

Opera-se mudança geral nos capacetes em meados do século XVI; e parte da oficialidade e dos cavaleiros que se armam para combater a pé, adotam uma espécie de celada de transição, que se aproxima da borguinhona.

Os infantes usam duas espécies de capacete. Uma delas é o morrião (Fig. 22-23), de timbre oval muito elevado, encimado por uma crista vertical, com mais de uma polegada de elevação no topo e seguindo todo o diâmetro, rodeado na base por duas virolas ou abas, que se encurvam sôbre as orelhas e se erguem na frente e na nuca, encontrando-se em bico recurvado para cima; é usada esta espécie pelos alabardeiros, arcabuzeiros e mosqueteiros. A outra variedade dêste capacete é o chamado cabasset pear-helm dos inglêses ou cabacete dos espanhóis.

O cabacete (Fig. 23-24) tem o timbre oval ou antes ogival com uma aresta viva muito pronunciada desde a cara até à

(11). - Couro curtido com tanino. 
nuca, terminando em bico no topo; não tem crista ou cimeira; na base remata em aba ou virola horizontal, estreita; é distituído de elegância; foi usado pelos piqueiros ou chuceiros.

Criaram-se também tipos mistos, como o cabacete-morrião, a celada-morrião, que é um morrião com pretensões clássicas de guarda-nuca e jugulares, e que muitas vêzes se confunde ccm a borgonhesa.

Os chefes usaram muito do capacete à romana, anacronismo pretencioso, destoando absolutamente do tipo dos trajes e armas da época. Notável contudo pela riqueza e excelência arística dos lavores que com freqüência o adornaram, formando decorações, fato aliás comum a tôdas as armas da época, muito mais próprias para figurar num gomil, numa salva ou noutra qualquer peça de baixela, do que num petrecho de guerra.

A coleção de Ambras em Viena d'Austria e a Armeria de Madrí encerram os mais valiosos exemplares desta arma, a qual está ligada por forma indissolúvel o nome do célebre escultor e armeiro italiano Lucio Peccinini.

Das armas de haste apenas três eram de uso geral nos meados do século XVI: a alabarda, a partasana, o chuço, o espontão ou chuço de sargento.

Deparamos ainda no século XVII com a fórmula derradeira do chapéu de ferro; é o feltro de aba larga tão conhecido pelos quadros e gravuras da época, mas de ferro; pouco tempo durou essa arma incômoda.

Uma outra arma cujo uso se prolongou até tarde foi o eisenkapt (o pot-en-tête dos franceses) que em Portugal se chamou panela de ferro ou panelão, e do qual é feita menção na descrição do primeiro cêrca de Diu. Usava-se, para nas investidas das muralhas defender a cabeça contra os projéteis e materiais inflamantes, e punha-se em cima do capacete.

As armas de torneio, com todos os seus exageros, acabam verdadeiramente no meado do século XVI, e tudo o que dêsse gêner ose encontra em coleções não deve considerar-se posterior a 1550 ou 1560 .

As diferentes variantes do escudo, salvo a rodela, já pouco se usavam, a não ser nos assédios; essas riquíssimas adargas e broquéis de formas neo-clássicas e de profusa ornamentação eram arma de luxo e quase sempre centros de panóplia, servindo quando muito nos cortejos triunfais, renovados por imitação da Antigüidade clássica. 
Acompanhamos assim a armadura em tôdas as suas fases e até a sua extinção no século XVIII, no decorrer do qual só duas peças defensivas restavam o capacete e a couraça.

O primeiro apresenta no século XVIII dois tipos diferentes, bem conhecidos e vulgarizados pelas gravuras de batalhas: o capacete redondo, orlado de pele de tigre e com cimeira enfeitada de penachos e crina pendente do guarda-nuca, foi o adotado pelos dragões, couraceiros e cavalaria pesada em geral; o outro é o capacete de sola, oval, de cimeira de crinas, de penas ou de lã cardada, que o acompanha recurvando-se da pala até a nuca. A couraça passou a ser arma exclusiva dos couraceiros a cavalo.

Voltemos a ocupar-nos da espada que é a arma mais verdadeiramente digna de atenção nos períodos posteriores à evolução do Renascimento .

Quando cairam em desuso as justas e os torneios, começaram a tomar incremento os duelos e com êstes o aperfeiçoamento do jôgo das armas de punho. Nasce então a esgrima, que vem do alemão schirmen, e não do italiano scherma como querem alguns. Entretanto, segundo autoridades modernas, a esgrima parece ter tido a sua origem na Espanha durante o govêrno de Carlos $V$.

Êste fato explica a importância que assumem a espada e o punhal durante o período do Renascimento, até que as repetidas proibições e medidas enérgicas de repressão, a que deu lugar em quase tôda a Europa a mania dos desafios e combates noturnos nas ruas das cidades, convertem a espada em arma privativa de militares, e condenam o punhal como arma ilícita, resultando no século XVIII a decadência absoluta destas: armas.

A espada do Renascimento tem uma feição característica. que a distingue da dos períodos anteriores; ao punho, até então em cruz, acrescenta-se um varão semi-circular para defesa da face dorsal da mão. Pouco a pouco se lhe vão acrescentando mais peças: ao varão reto horizontal (os quartões) que forma como que os braços da cruz, sobrepõe-se outro varão cujas extremidades recuam para o punho, e dois argolões que por baixo dos quartões vão prender ao espigão da fôlha. Êste é o tipo dominante da espada durante quase tôdas as três partes do século XVI.

Depois, vai-se multiplicando gradualmente o número dos varões que formam o guarda-mão; e vemos êste recurvar-se em espiral, em direções várias, disposição esta que os artistas apro- 
veitam para a sobrecarregar com lavores em relêvo, em gravura, embutidos e esmaltes por vêzes riquíssimos; muitas das espadas que nos restam dos fins do século XVI são verdadeiras maravilhas artísticas.

Os mais notáveis centros de fabricação de espadas foram, e continuaram a ser por longo tempo, Toledo e Sevilha, na Espanha, Solingen, na Alemanha central. Em Portugal existem muitas espadas com êste último nome gravado na fôlha.

Até ao meado do século XVII as guardas da empunhadeira das espadas são ainda mais complexas: as guardas e contraguardas descrevem por baixo dos quartões e na direção da fôlha curvas quase tão complicadas como as da parte superior ou guarda-mão.

Os tipos principais da espada quinhentista, alguns dos quais atravessaram ainda uma parte da centúria imediata, são os que passamos a apontar.

A espada pròpriamente dita tem a fôlha reta, lisa, e com largura de uma polegada; é sempre de dois gumes e aguda na extremidade; o nome espadão, do italiano spadone, é vocábulo que a princípio designou a espada de ambas as mãos e que se ficou aplicando a tôda e qualquer espada longa e de fôlha larga.

O rapier, espada alemã, que foi sempre arma de duelo, variante do estoque, ou espada para ferir de ponta, era tão longo e tão pesado quase como o espadão, tendo na base da empunhadeira uma chave dupla, em forma de concha, e geralmente crivada de orifícios.

O estoque descende do "estoque de duas mãos" dos cavaleiros do período ogival, reduzidas as suas dimensões e torna-se arma de duelo e arma traiçoeira, sendo por isso a mais perseguida e sujeita a proibições.

$O$ chifarote (bracquemart), espada larga e curta, aguçando para a ponta, e que parece ter sido uma imitação do paragonium romano, já foi usado pelos peöes no século $\mathrm{XV}$, e continuado no XVI, sujeitando-se-lhe a empunhadura ao sistema das guardas fechadas da época.

O malchus constitui variante do chifarote, que é hoje difícil distinguir daquele; tem contudo quase sempre um guarda-mão simples que liga com os quartões, a parte anterior dos quais recua para baixo como a do sabre de polícia.

O sabre, do alemão soebel, aparece durante alguns anos no meado do século XVI, e, segundo tôdas as probabilidades, por imitação das espadas dos húngaros ou dos turcos; parti- 
cipa do sabre moderno e do alfange ou cimitarra oriental; o punho curva-se em sentido oposto à lâmina, e o quarda-mão é interrompido, não se ligando ao pomo da empunhadeira, que representa quase sempre uma cabeça de animal fantástico.

A esclavônia, do italiano schiavona, cuja fôlha tem o comprimento e a forma do moderno sabre, um só gume, e cujo guarda-mão tem as guardas e contra-guardas reunidas numa só peça rendilhada em linhas geométricas, foi por muito tempo confundida com o claymore escocês; adotaram-na efetivamente primeiro alguns regimentos de cavalaria escocesa nos fins do século XVII, e usou-a a cavalaria desde princípios até meados do século XVIII.

A tarasca, em francês flamberge era uma espada possante, de guardas e contra-guardas complicadíssimas, de longa empunhadura, e cuja fôlha se apresentava ondeada ou em espiral morrendo em ponta aguda e de dois gumes; parece ter sido muito usada na defesa de muralhas durante os assailtos (12).

O verdugo, corruptela de Yverdon, na Suiça, lugar onde se fabricava, era uma espada esguia, de fôlha triangular ou facetada, quase em forma de espêto e em extremo comprida; constituiu arma de duelo nos séculos XVII e XVIII; variante do estoque, foi como êle muito perseguida. Encontram-se em Portugal exemplares e parece ter sido usada em duelos.

A espada preta, colichemarde, corruptela de koenigsmark, espada favorita de duelo no século XVII e ainda em parte do século XVIII, é muito comprida e larga de fôlha até ao meio desta, estreitando sùbitamente e rematando em ponta de estoque; tal disposição que equilibrava o pêso, pondo o centro de gravidade na empunhadura, tornava-a de um manêjo muito cômodo e ligeiro.

Do meado do século XVII em diante a empunhadura simplifica-se, o comprimento dos quartões exagera-se, e há por baixo uma espécie de tigela de ferro; a empunhadura é bastante curta, e o guarda-mão é singelo. Em Portugal abundam as armas dêste teor, e o seu uso prolongou-se até quase aos fins do século XVIII.

Do meado do século XVIII em diante a espada entra em rápida decadência; é quase substituída pelo sabre, de forma

12). - E' de origem alemã; descende da enorme espada de duas mãos dos suiços. E' desta espécie a espada de Vasco da Gama que existe em Vidigueira no Distrito de Beja, Portugal. 
pouco graciosa. Outro tipo encontramos ainda no século XVIII: o espadim ou faim, espada de corte, descendente do florete de jógo, verdadeiro enfeite, cuja fôlha foi freqüentemente substituída por uma barba de baleia.

Em nossos dias o sabre suplantou a espada, assumindo forma mais severa e marcial; caiu, como tôdas as armas contemporâneas, em tipo fixo, fabricado em série e desprovido de qualquer interêsse artístico.

O punhal e a adaga, acompanham quase em paralelo as evoluções da espada, copiando-lhe as formas; durante o Renascimento até aos fins do século XVII é a arma da mão esquerida nos duelos e serve para aparar certos golpes da espada.

O punhal foi uma das armas mais artísticas e das que maiores pretextos ofereceram para a ornamentação que, além dos copos e guardas, reclamava por vêzes também a bainha. Do século XVII em diante cai em desuso, e fica existindo apenas como arma clandestina, a não ser que se classifiquem como punhais essas armas que ainda hoje se vêm pendurados nos talins dos cadetes da Escola de Aeronáutica e dos aspirantes a guarda-marinhas da Escola Naval. Nas coleções há exemplares complicadíssimos e de serventia dupla, de molas de segrêdo, com pistolas, etc.

Os punhais ou facas dos lansquenetes ou landsknechts, alemães tinham na bainha duas ou mais facas pequeninas, os bastardos, que serviam, entre outros usos, para cortar as correias da armadura dos cavaleiros derrubados.

Poderíamos 'mencionar ainda o dirk, escocês, na bainha do qual há lugar para alojar-se exteriormente uma faca ou punhal menor e muitas vêzes um outro ainda menor ou garfo com colher articulados.

Mencionamos agora a baioneta, que data do princípio do século XVII. Primitivamente a baioneta introduzia-se no cano da espingarda, o que prejudicava o tiro, ou melhor o impedia. Sebastião Le Pretre, Senhor de Vauban (1633-1707), inventou um dispositivo que permitia fixá-la na bôca da espingarda sem aquêle inconveniente, podendo ser simultâneamente usada. o sabre-baioneta, veio substituir a baioneta como arma mais útil na defesa pessoal ou em campanha. Embora não pertença mais a armaria, poderíamos mencionar a faca de trincheira, cujo punho era um sôco inglês, usada na guerra de 1914-1918 e a faca comando, usada na II Guerra Mundial, de 1939-1945. 


\section{VI. - As armas de fogo}

O tipo primitivo das armas de fogo é a columbrina de mão cu colubrina, cópia em escala reduzida do trom ou canhão no período rudimentar: meia dúzia de robustas lâminas de ferro cintadas de anéis do mesmo metal, e mais tarde um canu:do, que se carregava de pólvora e ao qual pelo orifício ou ouvido se dava fogo com um morrão, acrescendo uma forquilha portátil que servia de descanço à arma.

Este petrecho de guerra, mais terrível quase sempre para o atirador do que para o seu contrário ,era sujeito a rebentar; seu aparecimento dá-se no século XIV, passando por sucessivos aperfeiçoamentos até ao princípio do século XVI, quando o seu emprêgo generalizou-se.

Começa, porém, a apresentar interêsse artístico no segundo quartel do século XIX, no qual encontramos o arcabuz (Fig. 30), munido de uma coronha tosca e pesada ainda e de manêjo incômodo, mas já com fecharia e gatilho para disparar o tiro; operando-se a percussão para o lado da coronha, e ameaçando assim de chamuscar o bigode do arcabuzeiro; a pontaria é feita descançando a arma sôbre uma forquilha de ferro.

Como sistema de fabrico, estacionou algum tempo; mas a arte apoderou-se dela e sujeitou-a a formas e ornamentações variadas, ocupando em breve um lugar distinto entre as armas de luxo.

Em 1560 já existia o mosquete (Fig. 31), modificação do arcabuz, mais aproximada da espingarda, cuja origem é duvidosa, atribuindo-a uns aos espanhóis e outros aos alemães. O mosquete distinguiu-se do arcabuz pelo adarme mais avanaperfeiçoamento da forma, era mais equilibrado e mais leve tajado, isto é, por ser arma de maior calibre; contudo, pelo do que o arcabuz e dispensava a forquilha de descanso.

A invenção do arcabuz criou um novo utensílio, o polvorinho, muito interessante como objeto de arte, e que desde $o$ meado do século XVI até ao do XVII (em que foi substituído pela bandoleira de cartuchos pendentes, já preparados e resguardados em tubos de metal), é por vêzes adornado com esculturas, tauchiado e enriquecido com embutidos nada inferiores em profusão e gôsto artístico aos que se empregavam nas coronhas dos arcabuzes e mosquetes. 
O mosquete do século XVII é quase sempre de redete ou roda, isto é, com fechos que funcionavam por meio de um tambor denticulado, pôsto em contacto com uma mola elástica, a que o gatilho comunicava ação, fazendo cair o cão, o qual tinha instalada uma lasca de pirite de ferro que incendiava por meio da faisca a pólvora do ouvido.

Éste novo invento fêz desaparecer, além da forquilha (que às vêzes era muito adornada e com a serventia dupla de lança e até de espada), um outro objeto, o porta-morrão, peça de ferro terminando em gancho e muito artisticamente elaborada, que servia de suspensor ao morrão que o arcabuzeiro trazia pendente ao cinturão.

No último quartel do século XVII os fechos funcionam já no sentido hoje adotado, isto é, operando-se a percussão para o lado do cano; e em 1670 já era conhecido o mosquete ou espingarda de fuzil e pederneira, que dessa época em diante perde gradualmente o interêsse, pela falta de elegância.

A espingarda (que parece vir do alemão springen, porém já se encontra mencionada em Portugal, em princípios do século XVI) no século XVIII muito embora mais perfeita no tiro, sofre o destino comum às armas dêsse período; é feia, tem coronha romba e massuda, cai logo em tipo fixo, passando desde o princípio do século XVIII a oferecer ùnicamente valor científico. A espingarda de fulminante, tipo que dominou até o século XIX, é invenção do escocês Forseth, em 1807.

A pistola foi, entre tôdas as armas de fogo do século XVI, talvez a mais artística, e é, sem dúvida, aquela de que restam exemplares mais artísticos nas coleções, quer de museus, quer particulares.

Esta arma, cujo nome deriva com mais probabilidade do italiano pistollo ("pomo ou remate de coronha") do que de pistoja, como querem alguns autores, parece ter sido primeiro fabricada em Perúgia, ou melhor, Perusa, na Itália, nos fins do século XIV, com forma tão rudimentar como as primeiras columbrinas ou colubrinas portáteis, e não excedendo a sua dimensão máxima um palmo.

Passou a pistola, pouco mais ou menos, por evoluções e melhoramentos idênticos aos da espingarda; contudo, o seu tipo especial parece ter-se fixado mais cêdo, visto que era já uma arma quase sempre elegantíssima aí por 1560 , fazendo então, como hoje, parte do armamento da cavalaria.

Até ao meado do século XVII o ginete usava uma só dessas armas: o pistolão (o petrinal ou pedreñal dos espanhóis, 
que muito concorreram para o seu aperfeiçoamento). $O$ pistolão pendia enganchado de uma argola no cinturão do militar. As pistolas dêsse período destacam-se nas coleções pela variedade e rara elegância de contôrno e pela delicadeza artística de ornamentação; até ao século XVII a coronha era quase sempre de metal lavrado. As pistolas, cuja coronha bastante longa e rematando em bola forma ângulo reto com o cano da arma, devem classificar-se entre as armas do século XVII; são as mais ingratas de feitio. Por essa época começa a usar-se o par de pistolas, e às selas adicionam-se os coldres.

Deu-se com esta arma uma singularidade, devida talvez a ser de dimensão menor do que as outras armas explosivas: é a tendência que apresenta, durante perto de um século, de ser aproveitada como arma de dupla serventia. Os museus e coleções possuem abundantes exemplares desta arma, os quais são simultâneamente pistola e espada, pistola-acha de armas, pistola-punhal, porque as armas de segrêdo foram uma das manias do baixo Renascimento.

O pior período da pistola é o que vai de 1780 a 1820 , em que os espingardeiros inglêses criaram êsses perfeitos espécimes, que como armas de duelo, se encontravam ainda, na "Belle Époque", nos gabinetes de grande parte dos indivíduos das classes elevadas.

Sugestionavam, de certa forma, aos fracos o suicídio; conforme o requinte do ambiente, como o famoso Cassino de Monte Carlo, no Principado de Mônaco, havia mesmo a Sala dos Suicidas, destinada aos que perdiam grandes somas no jôgo.

O bacamarte e tromblon, outra variante do arcabuz, espécie de canhão portátil de coronha, descendente do arcabuz primitivo; esta arma brutal, que se carregava de metralha, tinha o cano de grandíssimo adarme, alargando para a bôca. Era uma arma de marinha principalmente; foi também muito usada por bandidos e bandos de guerrilhas.

A escopeta é uma espingarda leve, geralmente usada para a caça.

A carabina é uma variante da espingarda, porém curta.

O esmerilão é uma enorme espingarda de cano muito longo, usado para a caça.

Há ainda as armas de vento, também chamadas armas surdas e que, por muito desleais, talvez por esta razão foram pouco usadas. 
Fazem parte dêsse grupo a sarabatana, tubo liso de comprimento variável e com uma embocadura, que servia para expelir balas materiais inflamáveis, setas por meio do sôpro. Esta arma, não é outra senão a usada empiricamente pelo nosso índio e é comum a outros indígenas do mundo. Foi usada por algum tempo nos assédios, depois ficou sendo apenas arma de caça.

Foram as armas de fogo e o invento da pólvora os agentes destruidores a que devemos a decadência e a extinção completa da armadura e das armas-brancas em geral, fato êsse que era de se esperar, pois uma vez que fabricamos armas em série, sujeitas a um tipo fixo de perfeição científica e industrial, não há lugar realmente, para armas de luxo, que demandam ùnicamente habilidade manual de um artesão especializado.

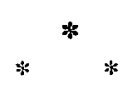

\section{Conclusões.}

A História da Arte da Armaria perde-se no espaço e no tempo e se confunde com a própria História do homem, muito embora seu nascimento, "com muitas reservas" podemos assinalar perto do século XIII, ou melhor no fim da Alta Idade Média, com muita razão e propriedade, pois é a época da realização da 4.a Cruzada (1202-1204) .

A par dêste movimento político-sócio-religioso $o_{\rtimes}$ que foram as Cruzadas, está ligado o movimento econômico do fim da Idade Média. Movimento êsse que tem base nas corporações de ofícios, onde o homem dedicava-se ao artesanato. Nas cidades medievais, onde deixara de existir o trabalho escravo, As corporações de ofícios acabaram abrangendo pràticamente a totalidade do artesanato. Juntamente com ela, nasceu o burguês, capaz de comprar quantas armaduras ou armas de luxo que aparecessem. Êle foi para a armaria um cliente certo, para quem o artista teve sempre trabalho. À medida que a armaria vai progredindo, o burguês também ia aumentando seu poderio econômico.

O Humanismo vai nos mostrar a desigualdade da indumentária do peão, que muito carecia de proteção, marchando a pé, protegendo o cavaleiro, que ia montado, pràticamente 
invulnerável, dentro de sua bem aparelhada armadura. O peão, embora desprotegido, tinha que facilitar a seu amo, a tarefa de receber em tempo hábil tôdas as armas de que ia necessitando durante o combate. Depois de derrubado o adversário, cumpria ao peão matá-lo e apoderar-se de suas armas.

O burguês pagava com a mesma satisfação exterior ao artesão que confecionava seu mosquete, ao artista que pintava o retrato de corpo inteiro de sua vigorosa mulher, cheia de jóias, em trajes domingueiros.

A Armaria tem nos séculos XIV, XV e XVI o seu período áureo, e nos fins do mesmo século XVII, o seu declínio. Que vamos encontrar como justificativa para êsse fato? $O$ aparecimento da pólvora é o primeiro golpe certeiro dado a tão graciosa e nobre arte. A armadura fica relegada ao luxo e é sem dúvida bem lançado deixar-se retratar o busto, guarnecido por um belo corselete, tendo sob o braço esquerdo um elegante elmo aberto e na mão direita, uma pistola ou uma espada de Toledo. Ésse requinte de harmonia ainda precisa da mão do armeiro.

A Armaria vai indiretamente influenciar a escultura tumular, pois não podemos imaginar o túmulo de rei ou de um nobre cavaleiro, que não tenha reproduzido em mármore para a posteridade seus feitos, aventuras e vitórias.

Nas grandes navegações ibéricas, não há necessidade de armadura, pois o homem vai viajar em clima geralmente tropical e o elemento que irá encontrar, o indígena, é inferior em cultura e desconhece o uso da pólvora, logo o elemento conquistador tem superioridade bélica.

No século XVIII, a Armaria entra em decadência e rápida extinção; o "seu cliente certo", agora não mais se interessa por ela, prefere cultivar artes mais amáveis e de salão, pois nas côrtes, também a Armaria já havia sido relegado ao plano de "coisa passada" e obsoleta.

Sòmente no segundo quartel do século XIX é que as atenções dos antiquários e dos artistas começaram a dirigir-se para o estudo das artes e das ciências da Idade Média, entre as quais a Armaria e daí a sua importância do seu estudo para -a História, como ciência auxiliar que é.

JOSUE' CALLANDER DOS REIS 


\section{BIBLIOGRAFIA UTILIZADA.}

BRIEUX (Eugène). - L'armature. Paris, 1905.

DUC (E. Viollet Le). - Diccionaire du mobilier français de l'époque Carlovingienne a la renaissance. Tome cinquième. $\mathrm{Pa}$ ris, s-d., 128-139-178-263-320-326-456.

GóES (Damião de). - Chronica do Principe Dom Ioam. Coimbra, Imprensa da Universidade, 1905.

HARLOR (Theodore). - The Benevenuto Cellini. Schapire, 1943.

LACOMBE (Paul). - Les armes et les Armures. Paris, 1868. 135.

L'Histoire de moyen âge et de la Renaissance. Paris, 1845. 5 vols.

LACROIX (Paul) . - XVIIIme Siècle Sciences et arts. Deuxième édition. Paris, $1878-521$.

- Usos, costumbres de la edad media y del Renacimiento. Madrí, 1925 .

- Vie militaires et religieuse au Moyen Áge et a l'époque de la Renaissance. Paris, 1876.

LAROUSSE de XIXeme siècle.

LiFE (Revista). - Evolução das armas. 5-X-1942.

LOPES (Fernão). - Chronica de El-Rei D. Fernando. Biblioteca de Clássicos Portuguêses. Lisboa, 1895.

MAINDRON (Maurice). - Les armes. Paris, 1890. 274-288-292.

PERES (Antônio Damião). - História de Portugal. Barcelos, Portucalense Editôra, 1928-1935.

PINA (Ruy de). - Duarte, o Eloqüente rei de Portugal, 1391-1436. Pôrto, 1914.

RESENDE (Garcia de), - Chronica de el-rei D. João II. Clássicos Portuguêses. Lisboa, 1902.

SANDE (Padre Duarte). - Arquivo Pitoresco. Agência de Ultramar. Lisboa, 1951.

SERE' (Fernando) e PAUL (Lacroix). - Estudos acêrca da Idade Média e da Renascença.

WEYGAND (Général), - Histoire de l’armée française. Paris, 1938. 